\title{
Gastrin-releasing peptide receptors in the central nervous system: role in brain function and as a drug target
}

\author{
Rafael Roesler ${ }^{1,2,3 *}$ and Gilberto Schwartsmann ${ }^{2,3,4}$ \\ 1 Laboratory of Neuropharmacology and Neural Tumor Biology, Department of Pharmacology, Institute for Basic Health Sciences, Federal University \\ of Rio Grande do Sul, Porto Alegre, Brazil \\ ${ }^{2}$ Cancer Research Laboratory, University Hospital Research Center (CPE-HCPA), Federal University of Rio Grande do Sul, Porto Alegre, Brazil \\ ${ }^{3}$ National Institute for Translational Medicine, Porto Alegre, Brazil \\ ${ }^{4}$ Department of Internal Medicine, School of Medicine, Federal University of Rio Grande do Sul, Porto Alegre, Brazil
}

\section{Edited by: \\ Hubert Vaudry, University of Rouen, \\ France}

\section{Reviewed by:}

Hélène Volkoff, Memorial University of Newfoundland, Canada

Mitsuhiro Kawata, Kyoto Prefectural

University of Medicine, Japan

\section{*Correspondence:}

Rafael Roesler, Laboratory of

Neuropharmacology and Neural Tumor Biology, Department of Pharmacology, Institute for Basic Health Sciences, Federal University of Rio Grande do Sul, 90050-170 Porto Alegre, Rio Grande do Sul, Brazil.

e-mail: rafael.roesler@pq.cnpq.br
Neuropeptides acting on specific cell membrane receptors of the G protein-coupled receptor (GPCR) superfamily regulate a range of important aspects of nervous and neuroendocrine function. Gastrin-releasing peptide (GRP) is a mammalian neuropeptide that binds to the GRP receptor (GRPR, BB2). Increasing evidence indicates that GRPR-mediated signaling in the central nervous system (CNS) plays an important role in regulating brain function, including aspects related to emotional responses, social interaction, memory, and feeding behavior. In addition, some alterations in GRP or GRPR expression or function have been described in patients with neurodegenerative, neurodevelopmental, and psychiatric disorders, as well as in brain tumors. Findings from preclinical models are consistent with the view that the GRPR might play a role in brain disorders, and raise the possibility that GRPR agonists might ameliorate cognitive and social deficits associated with neurological diseases, while antagonists may reduce anxiety and inhibit the growth of some types of brain cancer. Further preclinical and translational studies evaluating the potential therapeutic effects of GRPR ligands are warranted.

Keywords: gastrin-releasing peptide, gastrin-releasing peptide receptor, bombesin receptors, neuropeptide signaling, brain disorders

\section{INTRODUCTION}

Neuropeptide signaling regulates a variety of aspects of nervous and neuroendocrine function (Hökfelt et al., 2003; Salio et al., 2006). Neuropeptides act by activating specific cell membrane receptors that are members of the $G$ protein-coupled receptor (GPCR) superfamily, leading to stimulation of downstream protein kinase signaling pathways and ultimately altering gene expression (Oh et al., 2006).

Gastrin-releasing peptide (GRP), a neuropeptide originally isolated from the porcine stomach, is a 27 -amino acid peptide synthesized as a 148-amino acid precursor (PreproGRP) and subsequently metabolized posttranslationally (Spindel etal., 1984, 1990; Lebacq-Verheyden et al., 1988). GRP is the mammalian homolog of the amphibian 14-amino acid peptide bombesin, isolated from the skin of the European frog Bombina bombina in 1970 (Erspamer et al., 1970). GRP and bombesin display similar biological activities and share the same seven C-terminal amino acid sequence. Early experiments examining the effects of bombesin when administered in the brain showed that intracerebroventricular (i.c.v.) infusions of bombesin induced hypothermia and hyperglycemia in rats (Brown et al., 1977a,b). In peripheral tissues, the physiological functions of GRP include regulating gastrin and somatostatin release, gastric acid secretion, pancreatic secretion, gastrointestinal motility, lung development, and chemoattraction in immune system cells (Ruff et al., 1985; Schubert et al., 1991; Del Rio and De la Fuente, 1994; Niebergall-Roth and Singer, 2001; Ohki-Hamazaki et al., 2005; Gonzalez et al., 2008; Jensen et al., 2008b; Czepielewski et al., 2012). Another member of the bombesin-like peptide (BLP) family found in mammals is neuromedin $\mathrm{B}(\mathrm{NMB})$, the mammalian equivalent of ranatensin, which acts on the NMB receptor (NMBR; Minamino et al., 1983). An additional peptide originally named neuromedin C (NMC) is in fact a decapeptide of GRP (GRP-10, $\mathrm{GRP}_{18-27}$; Minamino et al., 1984). Thus, BLPs in mammalian tissues have been increasingly shown to constitute a class of signaling peptides regulating a large range of physiological functions.

Gastrin-releasing peptide acts by binding to the GRP receptor (GRPR, also called BB2), a GPCR that binds preferentially to GRP and bombesin, with much lower affinity for NMB (Jensen and Gardner, 1981; Moody et al., 1988, 1992; von Schrenck et al., 1989, 1990; Ladenheim et al., 1990, 1992; Wang et al., 1992). Increasing evidence indicates that GRPR-mediated signal transduction in the central nervous system (CNS) plays an important role in regulating behavior, especially aspects related to emotional responses, social interaction, memory, and feeding. In addition, we have proposed that dysfunctions in GRPR expression and signaling might play a role in CNS disorders including anxiety, autism, memory dysfunction associated with neurodegenerative disorders, and brain tumors. Here we review the role of GRPRs in regulating brain function, and its potential as a drug target for CNS disorders.

\section{MOLECULAR ORGANIZATION OF THE GRPR}

All mammalian bombesin receptors (GRPR, NMBR, and the orphan receptor BRS-3 or BB3) exhibit the characteristic seven 
transmembrane domain structure of GPCRs. This review will focus solely on the GRPR. For a comprehensive review of the classification, nomenclature, structure, expression, signaling, and functions of the different types of bombesin receptors, see Jensen et al. (2008b).

The GRPR, cloned from murine Swiss 3T3 cells in 1990 (Spindel et al., 1990; Battey et al., 1991), is a 384-amino acid protein in humans, mice, and rats. The chromosomal location for the GRPR gene (named GRPR in humans and Grpr in mice and rats) is at chromosome Xp22.2-p22.13 (human), X F4 (mouse), and Xq21 (rat; Jensen et al., 2008a; Table 1).

\section{GRPR SIGNALING}

Experiments using different types of normal and tumor cells from humans and rodents have provided consistent evidence that the GRPR is directly coupled to the $\mathrm{G}_{\mathrm{q}}$ type of $\mathrm{G}$ protein, and GRPR activation leads to an increase in cellular $\left[\mathrm{Ca}^{2+}\right]$ and stimulation of the phospholipase C (PLC)/protein kinase C (PKC) and extracellular signal-regulated protein kinase $(\mathrm{ERK}) /$ mitogen-activated protein kinase (MAPK) pathways (Hellmich et al., 1999; Chen and Kroog, 2004; Stangelberger et al., 2005). GRPR signaling also interacts with a range of other enzymes (e.g., phospholipases $\mathrm{A}_{2}$ and D, tyrosine kinases, phosphatidylinositol 3-kinase - PI3K, and ciclooxigenase-2), growth factor receptor systems (including epidermal growth factor receptor, EGFR, and TrkB), and

Table 1 | Molecular structure of the gastrin-releasing peptide receptor (GRPR).

\begin{tabular}{lllll}
\hline GRPR (BB2) & & & & \\
\hline Species & TM & AA & Chromosomal location & Gene name \\
Human & 7 & 384 & Xp22.2-p22.13 & GRPR \\
Rat & 7 & 384 & Xq21 & Grpr \\
Mouse & 7 & 384 & XF4 & Grpr \\
\hline
\end{tabular}

Aminoacid sequence (Homo sapiens)

$\begin{array}{lllll}\text { (1-60) } & \text { MALNDCFLLN } & \text { LEVDHFMHCN } & \text { ISSHSADLPV } & \text { NDDWSHPGIL } \\ & \text { YVIPAVYGVI } & \text { ILIGLIGNIT } & & \\ \text { (61-120) } & \text { LIKIFCTVKS } & \text { MRNVPNLFIS } & \text { SLALGDLLLL ITCAPVDASR } \\ & \text { YLADRWLFGR } & \text { IGCKLIPFIO } & & \\ (121-180) & \text { LTSVGVSVFT } & \text { LTALSADRYK } & \text { AIVRPMDIQA } & \text { SHALMKICLK } \\ & \text { AAFIWIISML } & \text { LAIPEAVFSD } & & \\ (181-240) & \text { LHPFHEESTN } & \text { OTFISCAPYP } & \text { HSNELHPKIH } & \text { SMASFLVFYV } \\ & \text { IPLSIISVYY } & \text { YFIAKNLIOS } & & \\ \text { (241-300) } & \text { AYNLPVEGNI } & \text { HVKKOIESRK } & \text { RLAKTVLVFV } & \text { GLFAFCWLPN } \\ & \text { HVIYLYRSYH } & \text { YSEVDTSMLH } & & \\ \text { (301-360) } & \text { FVTSICARLL } & \text { AFTNSCVNPF } & \text { ALYLLSKSFR } & \text { KOFNTQLLCC } \\ & \text { OPGLIIRSHS } & \text { TGRSTTCMTS } & & \\ \text { (361-384) } & \text { LKSTNPSVAT } & \text { FSLINGNICH } & \text { ERYV } & \end{array}$

Structural data are from Spindel etal. (1990), Battey etal. (1991), Wada etal. (1991), and Jensen etal. (2008a). Modified from Roesler etal. (2012), with permission). immediate-early genes (c-fos and c-jun; Szepeshazi et al., 1997; Chatzistamou et al., 2000; Thomas et al., 2005; Hohla et al., 2007; Ishola et al., 2007; Liu etal., 2007; Flores et al., 2008; de Farias et al., 2010; Czepielewski et al., 2012; Petronilho et al., 2012). Data on signaling mechanisms mediating GRPR actions specifically in the CNS will be discussed below.

\section{GRPR EXPRESSION IN THE CNS}

Early studies investigating the presence of bombesin receptors binding sites in the mammalian CNS showed that bombesin could bind with high affinity to rat brain membranes (Moody et al., 1978). Subsequently, autoradiographic studies indicated that areas containing high densities of GRPRs include the olfactory bulb, nucleus accumbens, caudate putamen, central amygdala, dorsal hippocampus, as well as the paraventricular, central medial, and paracentral thalamic nuclei (Wolf et al., 1983; Wolf and Moody, 1985; Zarbin et al., 1985). A detailed immunohistochemical characterization of GRPR expression in the mouse brain showed high GRPR immunoreactivity in the basolateral and central nuclei of the amygdala (BLA and CeA, respectively), hippocampus, hypothalamus, brain stem, nucleus tractus solitarius (NTS), and several cortical areas. Importantly, GRPR expression was restricted to neuronal cell bodies and dendrites, and was not present in axons or glial cells (Kamichi et al., 2005). Thus, the pattern of GRPR location in the brain suggests that it is specifically involved in regulating synaptic transmission. In some rat brain areas, GRPR expression shows marked changes during development - specifically between postnatal (PN) days 1 and 16 - with its expression increasing in the dentate gyrus and decreasing in the caudate putamen and lateral cerebellar nucleus (Wada et al., 1992).

Regarding receptor ligands, the use of radioimmunoassay techniques allowed demonstrating the presence of endogenous BLPs in the rat brain, with high concentrations in brain areas including the NTS, amygdala, and hypothalamus (Moody and Pert, 1979; Moody et al., 1981). GRP mRNA has the highest density in forebrain areas and hypothalamus (Wada et al., 1990; Battey and Wada, 1991; for reviews, see Moody and Merali, 2004; Roesler et al., 2006a; Jensen et al., 2008b).

In the rodent spinal cord, GRPR expression is restricted to lamina I of the dorsal spinal cord, and GRP is expressed in a subset of dorsal root ganglion neurons including lumbar spinothalamic neurons (Sun and Chen, 2007; Fleming et al., 2012; Kozyrev et al., 2012). Importantly, the GRP system in the spinal cord is sexually dimorphic. In male rats, neurons in the L3 and L4 levels of the lumbar spinal cord project to the lower lumbar spinal cord (L5-L6 level) and release GRP onto somatic and autonomic centers containing GRPRs, whereas this system is vestigial in females (Sakamoto et al., 2008; Sakamoto, 2011). This has important implications for the control of male sexual reflexes by GRPR signaling (see below).

\section{GRPR REGULATION OF CNS FUNCTION}

Evidence that GRPRs in the brain and spinal cord regulate several physiological functions has come mostly from in vivo studies using pharmacological or genetic manipulation of the GRPR in rats or mice. Below, we summarize relevant findings of selected studies 
focusing on GRPR regulation of memory, stress and anxiety responses, feeding, itching, and sexual behavior.

\section{SYNAPTIC PLASTICITY AND MEMORY}

In the late 1980s, Flood and Morley (1988) demonstrated that systemic or i.c.v. injections of GRP or bombesin after learning modulated memory retention for a T-maze footshock avoidance task in mice. When i.c.v. infusions were used, both peptides facilitated memory consolidation, whereas systemic injections produced memory enhancement or impairment depending on the drug dose and training conditions. Consistently with these findings, bombesin given after training through systemic injections (Rashidy-Pour and Razvani, 1998) or infusions directly into the NTS (Williams and McGaugh, 1994) enhanced memory retention in rats.

Memory modulation by GRPRs seems to be particularly important for memories involving emotional arousal and fear. Thus, pretraining injections of the GRPR antagonist [Leu13-(psi$\mathrm{CH}(2) \mathrm{NH}$ )-Leu14]BN impaired memory for inhibitory avoidance conditioning in mice (Santo-Yamada etal., 2003), and injection of another selective GRPR antagonist, RC-3095, in rats impaired memory for inhibitory avoidance but not for a task with less emotional content, novel object recognition (Roesler et al., 2004b). Similar impairing effects of RC-3095 on inhibitory avoidance memory were obtained with systemic posttraining injections (Roesler et al., 2004c), pre- or posttraining intrahippocampal microinfusions (Roesler et al., 2003; Venturella et al., 2005; Dantas et al., 2006; Preissler et al., 2007), or posttraining infusions into the BLA (Roesler et al., 2004c). The effects of the GRPR antagonist followed a typical inverted U-shaped dose-response pattern, in which intermediate doses resulted in memory impairment, whereas higher doses had no effect or produced memory enhancement (Roesler et al., 2003, 2004b; Dantas et al., 2006). Conversely, intrahippocampal infusion of bombesin resulted in enhancement of inhibitory avoidance memory at intermediate doses and impairment at higher doses (Roesler et al., 2006b). In addition to influencing memory formation, pharmacological manipulation GRPRs in specific brain areas has been shown to regulate fear memory expression, extinction, and reconsolidation-like processes (Luft et al., 2006, 2008; Mountney et al., 2006, 2008; Merali et al., 2011). For example, infusion of the GRPR antagonist RC-3095 into the rat dorsal hippocampus after memory reactivation blocks the extinction and reconsolidation of fear memory (Luft et al., 2006, 2008; for a review, see Roesler et al., 2012).

The role of GRPRs in regulating fear memory and synaptic plasticity has also been revealed by genetic studies using GRPR knockout mice. Contextual and cued fear conditioning were enhanced by the genetic deletion of GRPR, whereas spatial in the Morris water maze was unaffected. The enhancement of fear memory in GRPR knockout mice was accompanied by enhanced synaptic plasticity measured by long-term potentiation (LTP) in the amygdala. In wild-type mice, GRPR was preferentially expressed in amygdalar inhibitory interneurons releasing gamma-aminobutyric acid (GABA), and GRP might be released as a co-transmitter from glutamatergic neurons to activate preferentially GRPRs located on GABAergic interneurons to stimulate inhibitory transmission within the amygdala and function as an inhibitory constraint for the formation of fear-motivated memories (Shumyatsky et al., 2002).

Additional studies recently found enhanced retention and impaired extinction of cued fear conditioning, associated with an increase in c-fos activity in the BLA and reduced c-fos in the prefrontal cortex, in GRPR knockout mice. However, these mice showed unaltered contextual fear conditioning, multiple-trial cued fear conditioning, and conditioned taste aversion (Chaperon et al., 2012; Martel et al., 2012). Together, these findings indicate that the GRPR acts as a negative regulator of synaptic plasticity in the BLA and specific types of fear conditioning. However, the use of first generation knockout mouse models might confound the interpretation of the results, given that they do not allow the investigation of separate phases of memory (encoding, consolidation, and expression), and knockout mice might have up-regulation of compensatory pathways and non-specific alterations in CNS development in response to gene ablation (reviewed in Roesler et al., 2012).

We have shown that a number of signal transduction mechanisms downstream of receptor activation are involved in mediating memory regulation by the GRPR. In the CA1 area of the dorsal hippocampus, memory enhancement induced by bombesin was prevented by inhibitors of PKC, MAPK, PKA, and PI3K (Roesler et al., 2006b, 2009,2012), and potentiated by coinfusion of stimulators of the dopamine D1/D5 receptor (D1R)/cAMP/PKA pathway, namely the D1R agonist SKF 38393, the adenylyl cyclase activator forskolin, and the cAMP analog 8-Br-cAMP (Roesler et al., 2006b). These findings indicate that the PKC, MAPK, PI3K, and PKA pathways are critical in mediating memory modulation by hippocampal GRPRs, and that GRPR activation can interact with cAMP/PKA signaling in enhancing hippocampal memory formation (Figure 1). GRPRs in the rat brain also show functional interactions with other growth factor systems including basic fibroblast growth factor (bFGF/FGF-2), nerve growth factor (NGF), and brain-derived neurotrophic factor (BDNF; Kauer-Sant'Anna et al., 2007; Preissler et al., 2007).

\section{EMOTIONAL BEHAVIOR}

Gastrin-releasing peptide and GRPR are highly expressed in brain regions, such as the amygdala, activated by stressful stimuli, and, as discussed above, GRPR signaling is likely to be a major regulator of memory associated with fear and emotional arousal. Merali and colleagues have shown that chronic stressor exposure leads to an elevation of GRP levels in the anterior pituitary in rats, and GRP release in the rat amygdala is increased in response to exposure to a shock. GRP may stimulate the release of adrenocorticotropic hormone $(\mathrm{ACTH})$, playing a role in mediating the corticotropinreleasing hormone $(\mathrm{CRH})$ stress response, and increasing the activity of the hypothalamic-pituitary-adrenal (HPA) axis. In addition, bombesin administration induces endocrine, autonomic, and behavioral effects associated with stress, and bombesin receptor antagonists attenuate the behavioral and neurochemical effects of stressors (Merali et al., 2002, 2009; Moody and Merali, 2004; Mountney et al., 2011). Moreover, we have shown that systemic administration of a GRPR antagonist can induce an anxiogenic-like effect in the elevated plus maze test in rats 


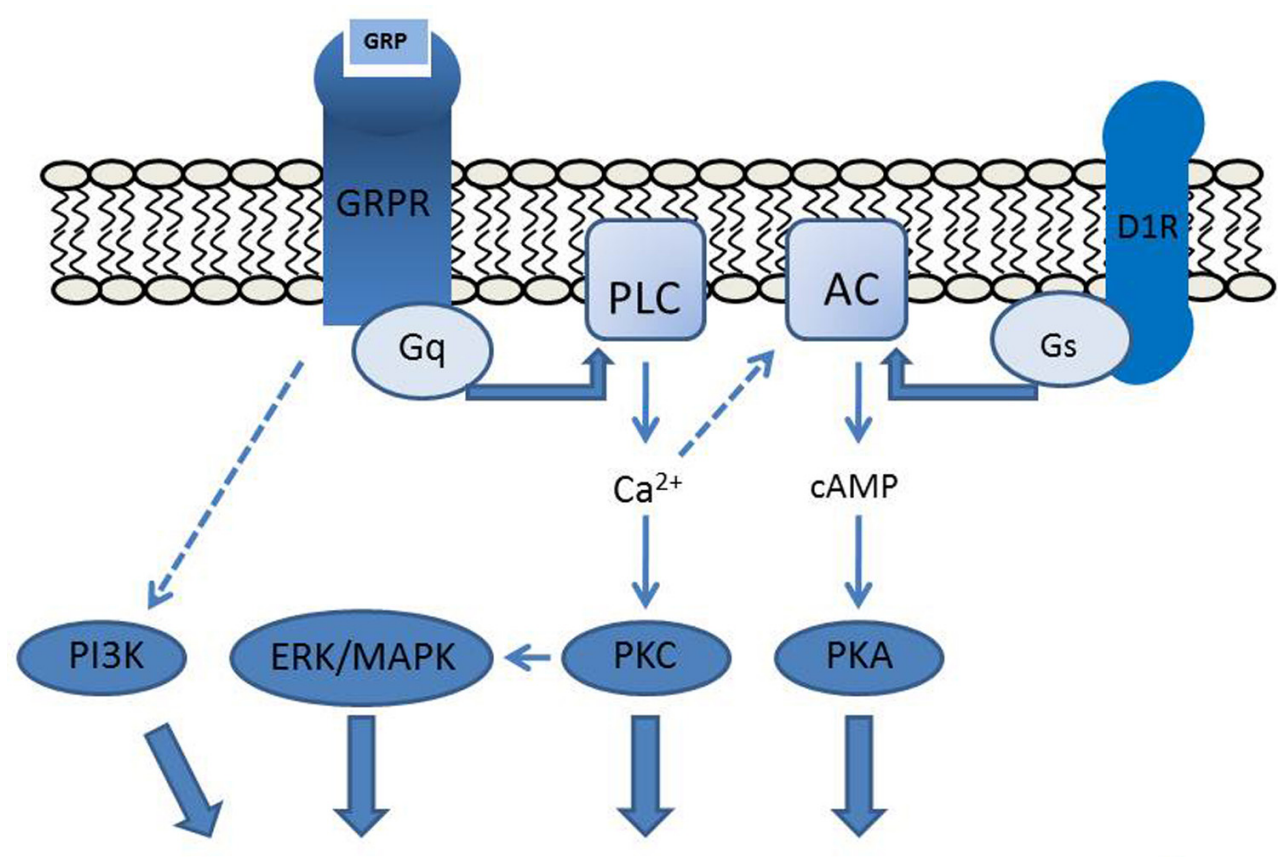

Stimulation of memory consolidation

FIGURE 1 | Proposed molecular mechanisms mediating GRPR regulation of brain function. The stimulation of hippocampal memory consolidation by GRPR activation depends on PKC, MAPK, PKA, and PI3K, and is potentiated by activation of the D1R/cAMP/PKA pathway (Roesler etal., 2006a, 2009, 2012). GRPR activation at the postsynaptic membrane is coupled to $\mathrm{G}_{\mathrm{q}}$ protein activity and increases in $\left[\mathrm{Ca}^{2+}\right]$, leading to stimulation of the PLC/PKC and ERK/MAPK pathways. D1R is coupled to the $\mathrm{G}_{\mathrm{s}}$ protein and adenylyl cyclase (AC) activation. The D1R-induced cAMP signal might be potentiated by $\left[\mathrm{Ca}^{2+}\right]$-induced stimulation of $\left[\mathrm{Ca}^{2+}\right]$-responsive types of AC Mong et al., 1999; Chan and Wong, 2005; Roesler et al., 2006b, 2012), providing a possible mechanism for the requirement of cAMP/PKA signaling for GRPR influences on memory. Modified from Roesler et al. (2006b, 2012), with permission.
(Martins et al., 2005). Together, these data suggest that brain GRPRs might regulate emotional behavioral and responses to stress.

\section{FEEDING BEHAVIOR}

It has been known for over 30 years that systemic or i.c.v. administration of bombesin or GRP in rats reduces the intake of liquid and solid food in rats (Gibbs et al., 1981). Similar effects on meal size are observed after systemic bombesin injections in mice and intravenous (i.v.) injections in baboons and humans (Gibbs, 1985). In addition, brief vena caval infusions of GRP and NMB in rats, given alone or together at the onset of the first nocturnal meal, significantly reduced meal size and duration (Rushing et al., 1996), and bombesin or GRP given systemically extended the duration of the intermeal interval (Thaw et al., 1998). The suppression of glucose intake induced by systemic administration of GRP or bombesin was blocked by infusion of a GRPR antagonist into the fourth ventricle in rats (Ladenheim et al., 1996), and was absent in GRPR knockout mice (Hampton et al., 1998; Ladenheim et al., 2002), indicating that central GRPRs are critical in mediating the effects of peripheral bombesin and GRP on feeding. In addition, GRPR knockout mice ate significantly more at each meal than wild-type controls (although total $24 \mathrm{~h}$ food consumption was equivalent), and showed elevated body weight compared with wild-type littermates beginning at 45 weeks of age (Ladenheim et al., 2002). The finding that systemic GRP potently reduced independent intake of both sucrose and milk from a bottle but did not affect intraoral intake of either solution indicated that the GRPR regulates the appetitive-related aspects of the feeding process (Rushing and Houpt, 1999). The amygdala is likely a key brain area involved in mediating the regulatory action of GRPRs on feeding: bilateral infusion of GRP into the central amygdala produced a transient inhibition of food intake, an effect that was prevented by the GRPR antagonist [Leu(13)-psi(CH(2)NH)-Leu(14)]BN (Fekete et al., 2002).

These findings provide strong support for a role of GRP/GRPR signaling in regulating feeding. It has been proposed that BLPs may also be released from the gastrointestinal tract in response to food ingestion, acting to bridge the gut and brain to inhibit further food intake. Conversely, the suppression of release of BLPs in the brain may trigger the initiation of a feeding episode (reviewed in Merali et al., 1999).

\section{SEXUAL BEHAVIOR}

One of the most exciting recent developments in GRPR research was the identification by Sakamoto etal. (2008) of a sexually dimorphic GRPR system in the spinal cord that is crucial in regulating male sexual function. In male rats, but not in 
females or males with a dysfunctional androgen receptor gene, GRP-containing neurons in the upper lumbar spinal cord innervate lower lumbar regions controlling erection and ejaculation. Pharmacological stimulation of spinal GRP receptors restores penile reflexes and ejaculation after castration, whereas intrathecal administration of the GRPR antagonist RC-3095 inhibits penile reflexes and ejaculations. The inhibitory effect of castration on GRP expression in this spinal center suggests that androgen signaling plays a major role in regulating GRP expression in the male spinal cord (Sakamoto et al., 2009b). Moreover, exposure to traumatic stress decreases the local GRP content and reduces penile reflexes in male rats (Sakamoto et al., 2009a; Sakamoto, 2010). Thus, GRP/GRPR signaling has emerged as a new target for the understanding of psychogenic erectile dysfunction and the development of potential therapeutic approaches to masculine reproductive dysfunction (Sakamoto et al., 2008, 2009a,b; Sakamoto and Kawata, 2009; Sakamoto, 2010, 2011).

\section{ITCHING}

Another function in which GRPRs in the spinal cord have been shown to play a major role is itching. GRPR knockout mice show normal thermal, mechanical, inflammatory, and pain responses, but reduced responses to pruritogenic stimuli, and GRP-induced pruritus in wild-type mice is blocked by intrathecal administration of a GRPR antagonist (Sun and Chen, 2007). The selective ablation of GRPR-expressing lamina I neurons in the mouse spinal cord of mice results in scratching deficits in response to itching stimuli, but does not affect pain behaviors (Sun et al., 2009). These findings allowed the identification of GRPR as a central molecular mediator of the itch sensation in the spinal cord (Sun and Chen, 2007; Sun et al., 2009).

A recent seminal study showed that the $\mu$-opioid receptor (MOR) isoform MOR1D heterodimerizes with GRPR in the spinal cord to relay itch information. Blocking the association between MOR1D and GRPR attenuates morphine-induced scratching. Morphine triggers internalization of both GRPR and MOR1D, whereas GRP specifically triggers both GRPR internalization and morphine-independent scratching. These data suggest that opioid-induced itch is independent of opioid analgesia and occurs via cross-activation of GRPR signaling by MOR1D heterodimerization (Liu et al., 2011).

\section{POSSIBLE ROLE OF ALTERATIONS IN GRPR EXPRESSION AND SIGNALING IN THE PATHOGENESIS OF BRAIN DISORDERS}

Since GRPRs are highly expressed in neurons in brain areas including the hippocampus and BLA, and regulate crucial aspects of behavior that can be altered in patients with CNS disorders, it is possible that deregulated GRPR signaling contribute to the pathogenesis of neurological and psychiatric diseases. Although a causative role of GRPR dysfunction in CNS disorders has not been directly established, some alterations in the levels of BLPs peptides or GRPR density or function have been observed in patients with psychiatric, neurodegenerative, and neurodevelopmental disorders. In addition, the use of preclinical models has provided further evidence indicating a role for the GRPR in some CNS pathologies. Based on these findings, we have put forward that the GRPR may be a novel molecular target for the development of therapeutic strategies for patients with neurological and psychiatric disorders (Roesler et al., 2004a, 2006a). Table 2 summarizes the findings from studies examining possible alterations in GRP and GRPR content or signaling found in patients with brain disorders.

\section{NEURODEGENERATIVE DISORDERS}

The concentration of BLPs was found to be significantly reduced in the caudate nucleus and globus pallidus of patients with Parkinson's disease (PD; Bissette et al., 1985). However, Stoddard et al. (1991) found no alterations in bombesin-like immunoreactivity in the adrenal medullary tissue of patients with $\mathrm{PD}$, although the concentration of several other neuropeptides was reduced. A reduction in bombesin receptor density and altered bombesin-induced calcium signaling have been reported in fibroblasts from patients with Alzheimer's disease (AD; Ito et al., 1994; Gibson et al., 1997).

Table 2 | Findings from selected studies examining possible alterations in the GRPR system in patients with CNS disorders. Modified from Roesler et al. (2006a), with permission.

\begin{tabular}{|c|c|c|}
\hline CNS disorder & Main findings & Reference \\
\hline Parkinson's disease & Reduced levels of BLPs peptides in caudate nucleus and globus pallidus & Bissette et al. (1985) \\
\hline Parkinson's disease & Normal bombesin-like immunoreactivity in adrenal medullary tissue & Stoddard et al. (1991) \\
\hline Alzheimer's disease & Reduced bombesin receptor density and enhanced bombesin-induced calcium release in fibroblasts & Ito etal. (1994) \\
\hline Alzheimer's disease & Reduced bombesin-induced calcium mobilization in fibrobasts & Gibson et al. (1997) \\
\hline Autism & $\mathrm{X} ; 8$ translocation in the GRPR gene & Ishikawa-Brush et al. (1997) \\
\hline Autism & No association with two polymorphic sites in the second exon of the GRPR gene & Marui et al. (2004) \\
\hline Autism & C6S and L181F mutations in the GRPR gene & Seidita et al. (2008) \\
\hline Schizophrenia & Reduced radioimmunoassay-detectable bombesin in the CSF & Gerner etal. (1985) \\
\hline Schizophrenia & Reduced urinary levels of BLPs & Olincy et al. (1999) \\
\hline Anxiety disorders & No association between GRP and GRPR genes and panic disorders & Hodges et al. (2009) \\
\hline Eating disorders & Reduced GRP levels in the CSF of women who were recovered from bulimia nervosa & Frank et al. (2001) \\
\hline Brain tumors & GRPR overexpression in glioma & Flores et al. (2010) \\
\hline
\end{tabular}




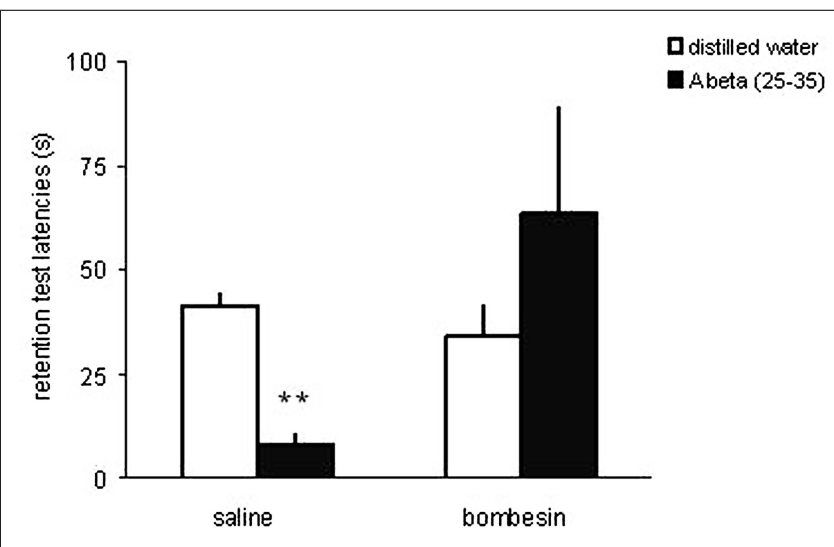

FIGURE 2 |The GRPR agonist bombesin prevents memory impairment induced by beta-amyloid peptide in the rat hippocampus. Data are mean \pm SEM retention test step-down latencies (s), in an inhibitory avoidance conditioning, of rats given a bilateral infusion of the GRPR agonist bombesin (BB; $0.002 \mu \mathrm{g}$ ) or saline (SAL; control group) 10 min before being trained in IA, and beta-amyloid peptide (Abeta; 25-35) or distilled water (DW; controls) immediately after IA training. The number of animals was 8-14 per group. ${ }^{*} P<0.01$ compared to the control group treated with SAL and DW. Reproduced from Roesler et al. (2006b), with permission.

For example, in fibroblasts from patients with familial AD presenting the Swedish APP670/671 mutation, elevations in calcium induced by bombesin were reduced by 40\% (Gibson et al., 1997).

Using the memory impairment produced by a microinfusion of a low dose of beta-amyloid peptide (25-35; Abeta) into the rat CA1 area of the dorsal hippocampus as a model of memory dysfunction associated with $\mathrm{AD}$, we showed that an intrahippocampal infusion of bombesin completely prevented the Abeta-induced impairment in inhibitory avoidance memory (Roesler et al., 2006b; Figure 2). This finding provided preliminary preclinical evidence suggesting that pharmacological stimulation of the GRPR might rescue memory deficits associated with AD.

\section{NEURODEVELOPMENTAL DISORDERS}

The first evidence suggesting that the GRPR might be a candidate gene in autism spectrum disorders (ASD) was the finding of a translocation breakpoint on the $\mathrm{X}$ chromosome in the first intron of the GRPR gene in a patient with autism accompanied by mental retardation and epilepsy (Ishikawa-Brush et al., 1997). Although a subsequent study investigating two polymorphic sites in the second exon of the GRPR gene in patients did not support the GRPR as a candidate locus for autism (Marui et al., 2004), more recently a possible role of C6S and L181F mutations of the GRPR gene in GRPR function and ASD was found in two patients (Seidita et al., 2008).

In order to examine the role of GRPR in CNS development and its possible involvement in ASD, we submitted rat pups to pharmacological GRPR blockade by systemic administration of RC-3095 from PN days 1-10, and examined long-lasting behavioral and molecular alterations produced by this treatment. Rats given neonatal RC-3095 showed pronounced deficits in social interaction (a hallmark of rodent models of ASD) when tested at PN days 30-35 (Presti-Torres et al., 2007; Figure 3) or PN day 60 (Presti-Torres et al., 2012). In addition, RC-3095-treated rats showed impaired 24-h retention of memory for inhibitory avoidance and novel object recognition, whereas body weight during development, open field behavior, and short-term memory were not affected (Presti-Torres et al., 2007, 2012). Neonatal GRPR blockade also reduced maternal odor preference, a behavioral measure of attachment behavior (Garcia et al., 2010). The impairment in social behavior induced by GRPR blockade was rescued by treatment with the atypical antipsychotic clozapine (Presti-Torres et al., 2012). Together, these findings suggest that GRPR blockade during CNS development can lead to specific behavioral alterations that are consistent with ASD, and support the possibility that abnormal GRPR expression or function during development might play a role in disease pathogenesis. Also, we have proposed that neonatal GRPR blockade in rats may serve as a novel animal model of ASD (Presti-Torres et al., 2007, 2012).

\section{OTHER NEUROPSYCHIATRIC DISORDERS}

The findings from rodent studies discussed above, indicating that normal GRPR function during development might be important for behaviors related to social interaction, attachment, and cognition, and that clozapine rescues social behavior deficits produced by GRPR blockade, are also consistent with the possibility that GRPR signaling is altered in schizophrenia. In addition, we found that GRPR blockade by systemic injections of RC-3095 prevent apomorphine-induced stereotypy in mice and amphetamine-induced hyperlocomotion in rats, which are models of schizophrenic psychosis and mania (Meller et al., 2004; KauerSant'Anna et al., 2007). In patients with schizophrenia, a reduction in the levels of radioimmunoassay-detectable bombesin in the cerebrospinal fluid (CSF; Gerner et al., 1985), and reduced urinary levels of BLPs (Olincy et al., 1999) have been found. Further studies using samples from patients and animal models are required to examine whether GRPR signaling is involved in schizophrenia.

As reviewed above, data from animal studies also consistently show that GRPRs in brain areas including the amygdala regulate memory related to fear and anxiety responses, raising the possibility that GRPR signaling plays a role in anxiety disorders (Moody and Merali, 2004; Roesler et al., 2012). For example, pharmacological manipulation of the GRPR in the hippocampus can affect extinction and reconsolidation of fear memory, which are preclinical models used in the investigation and screening of potential therapeutic strategies for post-traumatic stress disorder (PTSD) and other fear-related disorders (Luft et al., 2006, 2008). In postmortem analyses of brains from suicides compared to control subjects, Merali et al. (2006) reported discrete alterations in the levels of GRP and NMB. More recently, however, the possibility that GRP and GRPR are candidate genes in panic disorders was not confirmed in an association and linkage analysis (Hodges et al., 2009).

Anxiety disorders may show comorbidity with eating disorders, anorexia and bulimia nervosa. Given the important role of GRPR in regulating feeding behavior (see above), it is possible that it contributes to eating disorders. One study found significantly reduced GRP levels in the CSF of women who were recovered from bulimia nervosa, compared to women recovered from anorexia or healthy control women. The authors suggested that persistent alterations in GRP levels after recovery indicate that this alteration might be 
A

\section{saline}
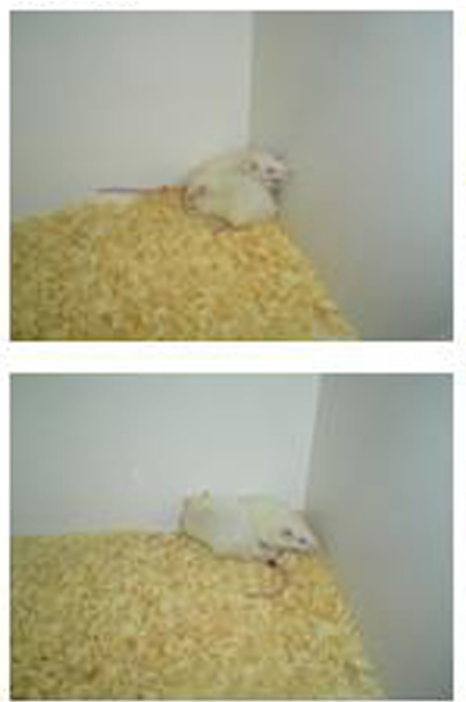

\section{RC-3095 $1 \mathrm{mg} / \mathrm{kg}$}
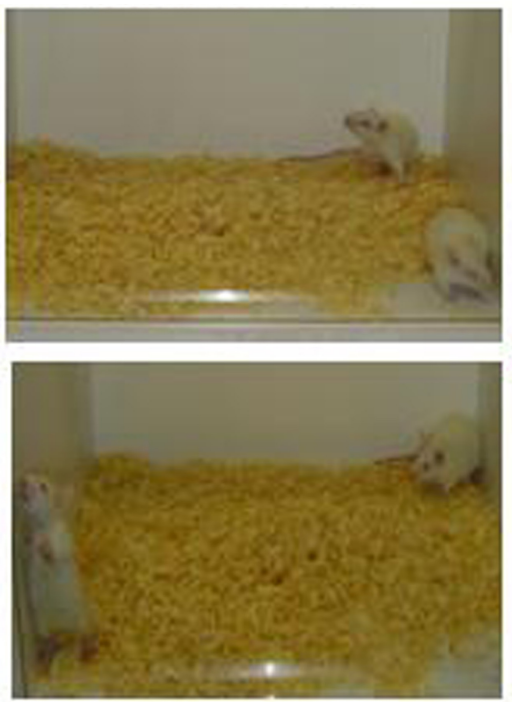

\section{$\mathrm{RC}-309510 \mathrm{mg} / \mathrm{kg}$}
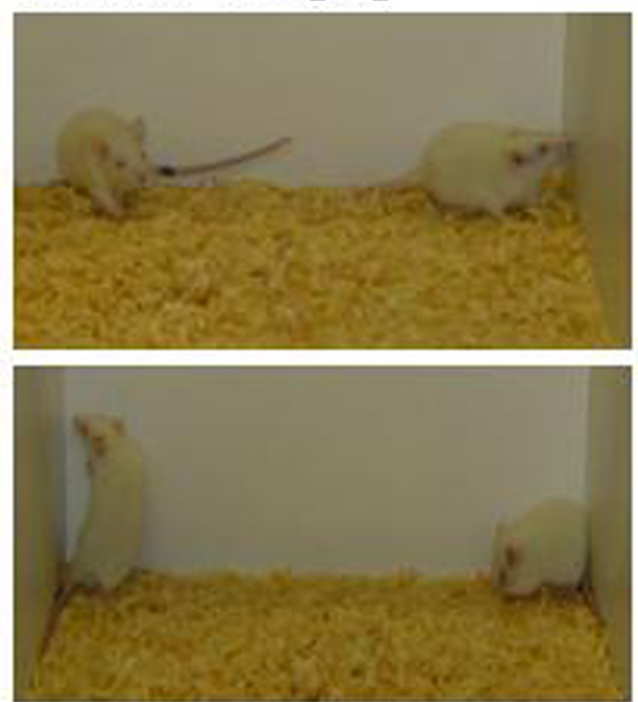

B

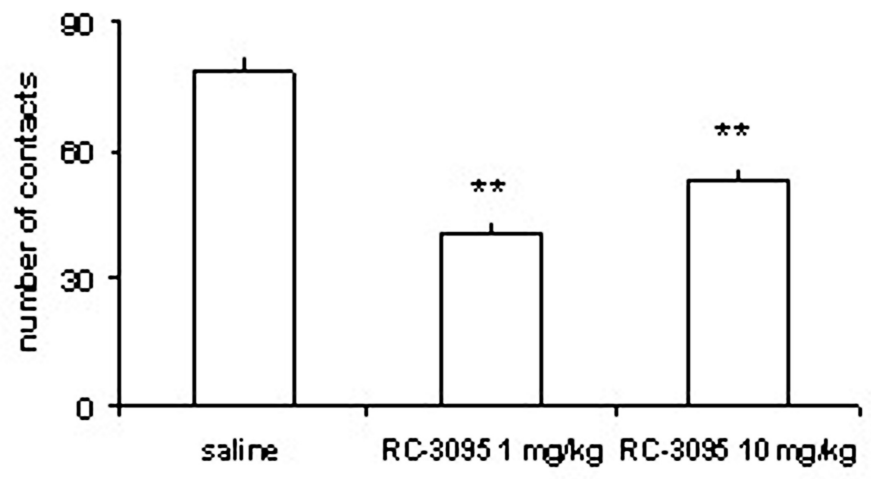

\section{C}

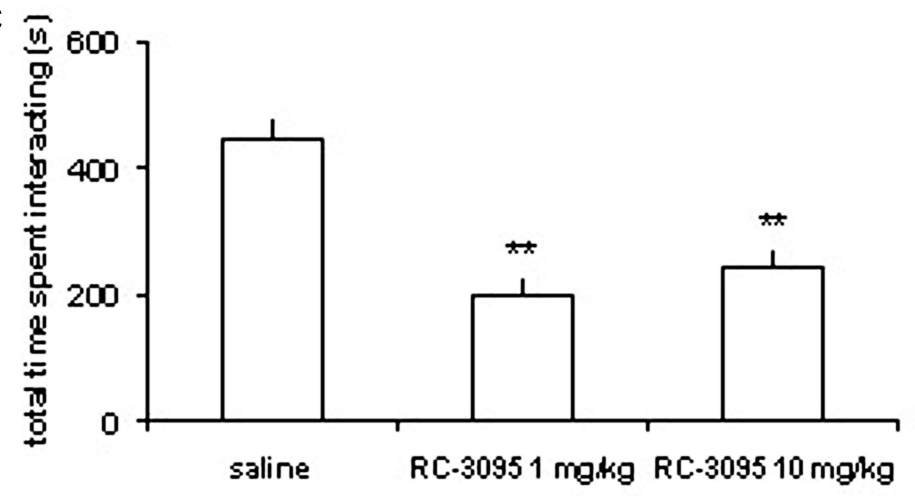

FIGURE 3 | GRPR blockade during CNS development in rats results in long-lasting behavioral alterations associated with experimental models of autistic spectrum disorders (ASDs). Rats were given intraperitoneal injections of saline (SAL; control group) or the GRPR antagonist RC-3095 (1 or $10 \mathrm{mg} / \mathrm{kg}$ ) twice daily from postnatal days (PN) 1 to 10. A social behavior test was carried out at PN 30. (A) Representative photographs of rats given SAL or RC-3095 (1 or $10 \mathrm{mg} / \mathrm{kg}$ ) during the social interaction test. (B) Mean \pm SEM number of social contacts. (C) Mean \pm SEM time spent engaged in social interaction (in seconds). The number of animals was $6-7$ per group; ${ }^{*} P<0.01$ compared to the control group. Reproduced from Presti-Torres etal. (2007), with permission. 
trait-related and contribute to episodic hyperphagia in patients with bulimia nervosa (Frank et al., 2001).

\section{BRAIN TUMORS}

Gastrin-releasing peptide receptor overexpression has been demonstrated in many types of cancer (Cornelio et al., 2007), and we have recently shown widespread expression and a high content of GRPR in human glioma, the most common and lethal type of neurological cancer (Flores et al., 2010; Figure 4). GRPR activation by GRP or bombesin stimulates the growth of glioma cell lines (Moody et al., 1989; Pinski et al., 1994; Sharif et al., 1997; de Farias et al., 2008; Flores et al., 2008). We have recently shown that the stimulatory effect of GRPR activation on proliferation of glioma cells depends on PI3K signaling (Flores et al., 2008) and is potentiated by co-activation of the cAMP/PKA pathway (de Farias et al., 2008; reviewed in Roesler et al., 2010).

Gastrin-releasing peptide receptor antagonists inhibit the growth of human U-87MG and U-373MG gliomas xenografted into nude mice (Pinski et al., 1994; Kiaris et al., 1999). In addition, GRPR antagonism by RC-3095, alone or combined with temozolomide, significantly reduced the growth of C6 gliomas both in vitro and in vivo, with the combined administration of TMZ and RC-3095 being the most effective treatment (Figure 5; de Oliveira et al., 2009). These findings strongly suggest that targeting GRPR may be a promising strategy for the development of novel therapies
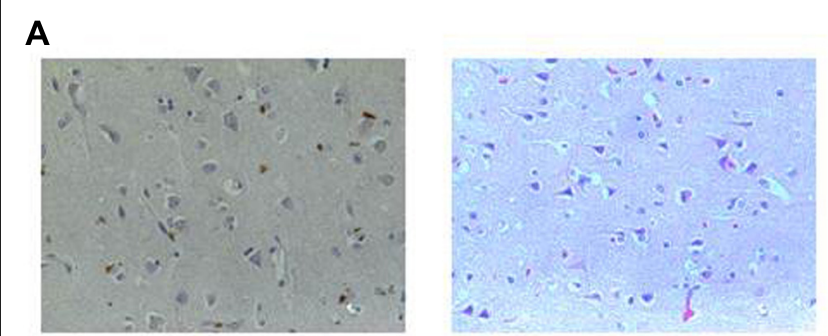

B
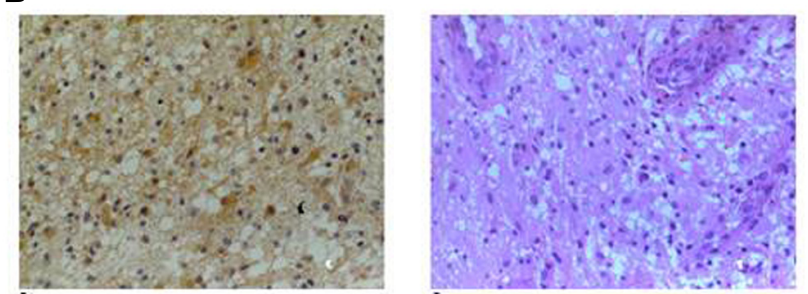

FIGURE 4 | GRPR content in human normal brain tissue and brain tumors. Representative sections of (A) normal brain and (B) astrocytoma grade IV from an immunohistochemical study of GRPR content from samples of patients with gliomas and normal brain samples. GRPR staining is shown in the right column (brown, $\times 400$ ) and hematoxylin-eosin (HE) in the left column $(\times 400)$. GRPR staining in the normal brain tissue is restricted to neuronal bodies and dendrites, whereas its presence in astrocytoma samples is widespread. Sections were incubated with anti-GRPR antibody, sequentially treated with biotinylated anti-rabbit lgG and streptavidin-biotin peroxidase solution, and then developed with diaminobenzidine as chromogen. Modified from Flores et al. (2010), with permission.

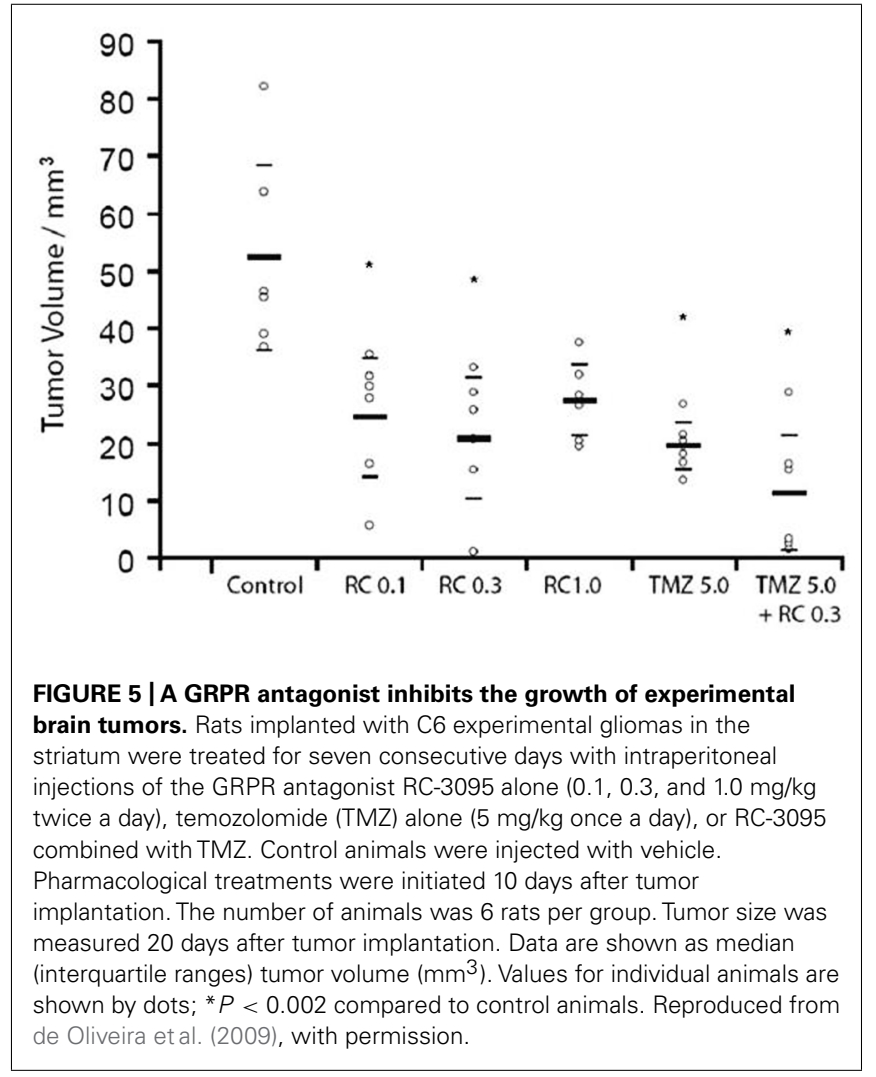

against glioma. The GRPR might also regulate the growth of neuroblastoma (Kim et al., 2002; Qiao et al., 2008; Abujamra et al., 2009), although, in contrast, we could not find a role for GRPR in regulating the in vitro growth of medulloblastoma, the most common brain cancer of childhood (Schmidt et al., 2009).

\section{GRPR LIGANDS AS CANDIDATE THERAPEUTIC DRUGS IN BRAIN DISORDERS}

The evidence reviewed above indicates that the GRPR might be considered a novel molecular target in different types of CNS disorders, and raise the possibility that GRPR agonists might ameliorate cognitive and social deficits associated with neurological diseases, while antagonists may, for example, reduce anxiety and inhibit the growth of some types of brain cancer. Studies examining the effects of GRP administration on satiety and eating behavior in humans (Gutzwiller et al., 1994), as well as a phase I trial of the GRPR antagonist RC-3095 in patients with solid tumors (Schwartsmann et al., 2006) have suggested that GRP and peptidergic GRPR antagonists can be safely administered intravenously in human subjects. Thus, the potential therapeutic effect of GRPR ligands in preclinical models as well as in patients with CNS disorders warrants further investigation.

\section{ACKNOWLEDGMENTS}

This work was supported by the National Council for Scientific and Technological Development (CNPq; grant number 303703/2009-1 to Rafael Roesler); the National Institute for Translational Medicine (INCT-TM); and the South American Office for Anticancer Drug Development. 


\section{REFERENCES}

Abujamra, A. L., Almeida, V. R. Brunetto, A. L., Schwartsmann, G. and Roesler, R. (2009). A gastrinreleasing peptide receptor antagonist stimulates Neuro2a neuroblastoma cell growth: prevention by a histone deacetylase inhibitor. Cell Biol. Int. 33, 899-903.

Battey, J., and Wada, E. (1991). Two distinct receptor subtypes for mammalian bombesin-like peptides. Trends Neurosci. 14, 524-528.

Battey, J. F., Way, J. M., Corjay, M. H., Shapira, H., Kusano, K., Harkins, R., et al. (1991). Molecular cloning of the bombesin/gastrin-releasing peptide receptor from Swiss 3T3 cells. Proc. Natl. Acad. Sci. U.S.A. 88, 395-399.

Bissette, G., Nemeroff, C. B., Decker, M. W., Kizer, J. S., Agid, Y., and Javoy-Agid, F. (1985). Alterations in regional brain concentrations of neurotensin and bombesin in Parkinson's disease. Ann. Neurol. 17, 324-328.

Brown, M., Rivier, J., and Vale, W. (1977a). Bombesin: potent effects on thermoregulation in the rat. Science 196, 998-1000.

Brown, M. R., Rivier, J., and Vale, W. W. (1977b). Bombesin affects the central nervous system to produce hyperglycemia in rats. Life Sci. 21, 1729-1734.

Chaperon, F., Fendt, M., Kelly, P. H., Lingenhoehl, K., Mosbacher, J., Olpe, H. R., et al. (2012). Gastrin-releasing peptide signaling plays a limited and subtle role in amygdala physiology and aversive memory. PLoS ONE 7:e34963. doi: 10.1371/journal.pone.0034963

Chan, A. S., and Wong, Y. H. (2005). Gq-mediated activation of c-Jun N-terminal kinase by the gastrin-releasing peptide-preferring bombesin receptor is inhibited upon costimulation of the Gs-coupled dopamine D1 receptor in COS-7 cells. Mol. Pharmacol. 68, 1354-1364.

Chatzistamou, I., Schally, A. V., Sun, B., Armatis, P., and Szepeshazi, K. (2000). Inhibition of growth of OV1063 human epithelial ovarian cancers and c- jun and c- fos oncogene expression by bombesin antagonists. Br. J. Cancer 83, 906-913.

Chen, P. W., and Kroog, G. S. (2004). Alterations in receptor expression or agonist concentration change the pathways gastrin-releasing peptide receptor uses to regulate extracellular signal-regulated kinase. Mol. Pharmacol. 66, 1625-1634.

Cornelio, D., Roesler, R., and Schwartsmann, G. (2007). Gastrin-releasing peptide receptor as a molecular target in experimental anticancer therapy. Ann. Oncol. 18, 1457-1466.

Czepielewski, R. S., Porto, B. N., Rizzo, L. B., Roesler, R., Abujamra, A. L., Pinto, L. G., et al. (2012). Gastrinreleasing peptide receptor (GRPR) mediates chemotaxis in neutrophils. Proc. Natl. Acad. Sci. U.S.A. 109 547-552.

Dantas, A. S., Luft, T., Henriques, J. A., Schwartsmann, G., and Roesler, R. (2006). Opposite effects of low and high doses of the gastrin-releasing peptide receptor antagonist RC-3095 on memory consolidation in the hippocampus: possible involvement of the GABAergic system. Peptides 27, 2307-2312.

de Farias, C. B., Lima, R. C., Lima, L. O., Flores, D. G., Meurer, L., Brunetto, A. L., et al. (2008). Stimulation of proliferation of U138-MG glioblastoma cells by gastrin-releasing peptide in combination with agents that enhance cAMP signaling. Oncology 75, 27-31.

de Farias, C. B., Rosemberg, D. B., Heinen, T. E., Koehler-Santos, P., Abujamra, A. L., Kapczinski, F., et al. (2010). BDNF/TrkB content and interaction with gastrinreleasing peptide receptor blockade in colorectal cancer. Oncology 79, 430-439.

de Oliveira, M. S., Cechim, G., Braganhol, E., Santos, D. G., Meurer, L., de Castro, C.G. Jr., et al. (2009). Anti-proliferative effect of the gastrin-release peptide receptor antagonist RC-3095 plus temozolomide in experimental glioblastoma models. J. Neurooncol. 93, 191-201.

Del Rio, M., and De la Fuente, M. (1994). Chemoattractant capacity of bombesin, gastrin-releasing peptide and neuromedin $\mathrm{C}$ is mediated through PKC activation in murine peritoneal leukocytes. Regul. Pept. 49, 185-193.

Erspamer, V., Erpamer, G. F., and Inselvini, M. (1970). Some pharmacological actions of alytesin and bombesin. J. Pharm. Pharmacol. 22, 875-876.

Fekete, E., Vígh, J., Bagi, E. E., and Lénárd, L. (2002). Gastrin-releasing peptide microinjected into the amygdala inhibits feeding. Brain Res. 955 55-63.

Fleming, M. S., Ramos, D., Han, S. B. Zhao, J., Son, Y. J., and Luo, W. (2012). The majority of dorsal spinal cord gastrin releasing peptide is synthesized locally whereas neuromedin B is highly expressed in pain- and itchsensing somatosensory neurons. $\mathrm{Mol}$. Pain 8, 52.
Flood, J. F., and Morley, J. E. (1988). Effects of bombesin and gastrinreleasing peptide on memory processing. Brain Res. 460, 314-322.

Flores, D. G., de Farias, C. B., Leites, J., de Oliveira, M. S., Lima, R. C., Tamajusuku, A. S., et al. (2008). Gastrin-releasing peptide receptors regulate proliferation of C6 Glioma cells through a phosphatidylinositol 3-kinase-dependent mechanism. Curr. Neurovasc. Res. 5, 99-105.

Flores, D. G., Meurer, L., Uberti, A. F., Macedo, B. R., Lenz, G., Brunetto, A. L., et al. (2010). Gastrin-releasing peptide receptor content in human glioma and normal brain. Brain Res. Bull. 82, 95-98.

Frank, G. K., Kaye, W. H., Ladenheim, E. E., and McConaha, C. (2001). Reduced gastrin releasing peptide in cerebrospinal fluid after recovery from bulimia nervosa. Appetite 37, 9-14.

Garcia, V. A., Dornelles, A. S., PrestiTorres, J., Alcalde, L. A., Halmenschlager, L. H., Schwartsmann, G., et al. (2010). Neonatal gastrinreleasing peptide receptor blockade reduces maternal odor preference in rats. Behav. Brain Res. 214 456-459.

Gerner, R. H., van Kammen, D. P., and Ninan, P. T. (1985). Cerebrospinal fluid cholecystokinin, bombesin and somatostatin in schizophrenia and normals. Prog. Neuropsychopharmacol. Biol. Psychiatry 9, 73-82.

Gibbs, J. (1985). Effect of bombesin on feeding behavior. Life Sci. 37, 147-153.

Gibbs, J., Kulkosky, P. J., and Smith, G. P. (1981). Effects of peripheral and central bombesin on feeding behavior of rats. Peptides 2(Suppl. 2), 179-183.

Gibson, G. E., Vestling, M., Zhang, H., Szolosi, S., Alkon, D., Lannfelt, L., et al. (1997). Abnormalities in Alzheimer's disease fibroblasts bearing the APP670/671 mutation. Neurobiol. Aging 18, 573-580.

Gonzalez, N., Moody, T. W., Igarashi, H., Ito, T., and Jensen, R. T. (2008). Bombesin-related peptides and their receptors: recent advances in their role in physiology and disease states. Curr. Opin. Endocrinol. Diabetes Obes. 15, 58-64.

Gutzwiller, J. P., Drewe, J., Hildebrand, P., Rossi, L., Lauper, J. Z., and Beglinger, C. (1994). Effect of intravenous human gastrin-releasing peptide on food intake in humans. Gastroenterology 106, 1168-1173.

Hampton, L. L., Ladenheim, E. E. Akeson, M., Way, J. M., Weber, H. C., Sutliff, V. E., et al. (1998). Loss of bombesin-induced feeding suppression in gastrin-releasing peptide receptor-deficient mice. Proc Natl. Acad. Sci. U.S.A. 95, 31883192.

Hellmich, M. R., Ives, K. L., Udupi, V., Soloff, M. S., Greeley, G.H. Jr., Christensen, B. N., et al. (1999). Multiple protein kinase pathways are involved in gastrin-releasing peptide receptorregulated secretion. J. Biol. Chem. 274, 23901-23909.

Hodges, L. M., Weissman, M. M., Haghighi, F., Costa, R., Bravo, O., Evgrafov, O., et al. (2009). Association and linkage analysis of candidate genes GRP, GRPR, CRHR1, and TACR1 in panic disorder. Am. J. Med. Genet. B Neuropsychiatr. Genet. 150B, 65-73.

Hökfelt, T., Bartfai, T., and Bloom, F. (2003). Neuropeptides: opportunities for drug discovery. Lancet Neurol. 2, 463-472.

Hohla, F., Schally, A. V., Kanashiro, C. A., Buchholz, S., Baker, B., Kannadka, C., et al. (2007). Growth inhibition of non-small-cell lung carcinoma by BN/GRP antagonist is linked with suppression of K-Ras, COX-2, and pAkt. Proc. Natl. Acad. Sci. U.S.A. 104, 18671-18676.

Ishikawa-Brush, Y., Powell. J. F., Bolton. P., Miller. A. P., Francis, F., Willard, H. F., et al. (1997). Autism and multiple exostoses associated with an $\mathrm{X} ; 8$ translocation occurring within the GRPR gene and 3' to the SDC2 gene. Hum. Mol. Genet. 6, 1241-1250.

Ishola, T. A., Kang, J., Qiao, J., Evers, B. M., and Chung, D. H. (2007). Phosphatidylinositol 3-kinase regulation of gastrin-releasing peptide-induced cell cycle progression in neuroblastoma cells. Biochim. Biophys. Acta 1770, 927-932.

Ito, E., Oka, K., Etcheberrigaray, R., Nelson, T. J., McPhie, D. L., Tofel-Grehl, B., et al. (1994). Internal $\mathrm{Ca}^{2+}$ mobilization is altered in fibroblasts from patients with Alzheimer disease. Proc. Natl. Acad. Sci. U.S.A. 91, 534-538.

Jensen, R. T., Battey, J. F., Benya, R. V., and Spindel, E. R. (2008a). Bombesin Receptors. IUPHAR Database (IUP$H A R-D B)$. Available at: http://www. iuphar-db.org/DATABASE/Family MenuForward?familyId=9 [accessed on October 1, 2012].

Jensen, R. T., Battey, J. F., Spindel, E. R., and Benya, R. V. (2008b). International Union of Pharmacology. LXVIII. Mammalian bombesin receptors: nomenclature, distribution, pharmacology, signaling, and functions in normal and disease states. Pharmacol. Rev. 60, 1-42.

Jensen, R. T., and Gardner, J. D. (1981). Identification and characterization of 
receptors for secretagogues on pancreatic acinar cells. Fed. Proc. 40, 2486-2496.

Kamichi, S., Wada, E., Aoki, S., Sekiguchi, M., Kimura, I., and Wada, K. (2005). Immunohistochemical localization of gastrin-releasing peptide receptor in the mouse brain. Brain Res. 1032, 162-170.

Kauer-Sant'Anna, M., Andreazza, A. C., Valvassori, S. S., Martins, M. R., Barbosa, L. M., Schwartsmann, G., et al. (2007). A gastrin-releasing peptide receptor antagonist blocks D-amphetamine-induced hyperlocomotion and increases hippocampal NGF and BDNF levels in rats. Peptides 28, 1447-1452.

Kiaris, H., Schally, A. V., Sun, B., Armatis, P., and Groot, K. (1999). Inhibition of growth of human malignant glioblastoma in nude mice by antagonists of bombesin/gastrin-releasing peptide. Oncogene 18, 7168-7173.

Kim, S., Hu, W., Kelly, D. R., Hellmich, M. R., Evers, B. M., and Chung, D. H. (2002). Gastrin-releasing peptide is a growth factor for human neuroblastomas. Ann. Surg. 235, 621-629.

Kozyrev, N., Lehman, M. N., and Coolen, L. M. (2012). Activation of gastrin-releasing peptide receptors in the lumbosacral spinal cord is required for ejaculation in male rats. J. Sex. Med. 9, 1303-1318.

Ladenheim, E. E., Hampton, L. L., Whitney, A. C., White, W. O., Battey, J. F., and Moran, T. H. (2002). Disruptions in feeding and body weight control in gastrin-releasing peptide receptor deficient mice. J. Endocrinol. 174, 273-281.

Ladenheim, E. E., Jensen, R. T., Mantey, S. A., McHugh, P. R., and Moran, T. H. (1990). Receptor heterogeneity for bombesin-like peptides in the rat central nervous system. Brain Res. 537, 233-240.

Ladenheim, E. E., Jensen, R. T., Mantey, S. A., McHugh, P. R., and Moran, T. H. (1992). Distinct distributions of bombesin receptor subtypes in the rat central nervous system. Brain Res. 593, 168-178.

Ladenheim, E. E., Taylor, J. E., Coy, D. H., Moore, K. A., and Moran, T. H. (1996). Hindbrain GRP receptor blockade antagonizes feeding suppression by peripherally administered GRP. Am. J. Physiol. 271(Pt 2), R180-R184.

Lebacq-Verheyden, A. M., Krystal, G., Sartor, O., Way, J., and Battey, J. F. (1988). The rat prepro gastrin releasing peptide gene is transcribed from two initiation sites in the brain. $\mathrm{Mol}$. Endocrinol. 2, 556-563.
Liu, X., Carlisle, D. L., Swick, M. C., Gaither-Davis, A., Grandis, J. R., and Siegfried, J. M. (2007). Gastrin-releasing peptide activates Akt through the epidermal growth factor receptor pathway and abrogates the effect of gefitinib. Exp. Cell Res. 313, 1361-1372.

Liu, X. Y., Liu, Z. C., Sun, Y. G., Ross, M., Kim, S., Tsai, F. F., et al. (2011). Unidirectional cross-activation of GRPR by MOR1D uncouples itch and analgesia induced by opioids. Cell 147, 447-458.

Luft, T., Amaral, O. B., Schwartsmann, G., and Roesler, R. (2008). Transient disruption of fear-related memory by post-retrieval inactivation of gastrin-releasing peptide or $N$-methyl-D-aspartate receptors in the hippocampus. Curr. Neurovasc Res. 5, 21-27.

Luft, T., Flores, D. G., Vianna, M R., Schwartsmann, G., Roesler, R., and Izquierdo, I. (2006). A role for hippocampal gastrin-releasing peptide receptors in extinction of aversive memory. Neuroreport 17 935-939.

Martel, G., Hevi, C., Wong, A., Zushida, K., Uchida, S., and Shumyatsky, G. P. (2012). Murine GRPR and stathmin control in opposite directions both cued fear extinction and neural activities of the amygdala and prefrontal cortex. PLoS ONE 7:e30942. doi: 10.1371/journal.pone.0030942

Martins, M. R., Reinke, A., Valvassori S. S., Machado, R. A., Quevedo, J., Schwartsmann, G., et al. (2005). Non-associative learning and anxiety in rats treated with a single systemic administration of the gastrinreleasing peptide receptor antagonist RC-3095. Peptides 26, 2525-2529.

Marui, T., Hashimoto, O., Nanba, E., Kato, C., Tochigi, M., Umekage, T., et al. (2004). Gastrin-releasing peptide receptor (GRPR) locus in Japanese subjects with autism. Brain Dev. 26, 5-7.

Meller, C. A., Henriques, J. A., Schwartsmann, G., and Roesler, R. (2004). The bombesin/gastrin releasing peptide receptor antagonist RC-3095 blocks apomorphine but not MK801 -induced stereotypy in mice. Peptides 25, 585-588.

Merali, Z., Hayley, S., Kent, P., McIntosh, J., Bédard, T., and Anisman, H. (2009). Impact of repeated stressor exposure on the release of corticotropin-releasing hormone, arginine-vasopressin and bombesinlike peptides at the anterior pituitary. Behav. Brain Res. 198, 105-112.

Merali, Z., Kent, P., and Anisman, H. (2002). Role of bombesin-related peptides in the mediation or integration of the stress response. Cell. Mol. Life Sci. 59, 272-287.

Merali, Z., Kent, P., Du, L., Hrdina, P., Palkovits, M., Faludi, G., et al. (2006). Corticotropin-releasing hormone, arginine vasopressin, gastrinreleasing peptide, and neuromedin $B$ alterations in stress-relevant brain regions of suicides and control subjects. Biol. Psychiatry 59, 594-602.

Merali, Z., McIntosh, J., and Anisman, H. (1999). Role of bombesin-related peptides in the control of food intake. Neuropeptides 33, 376-386.

Merali, Z., Mountney, C., Kent, P., and Anisman, H. (2011). Effects of intracerebral ventricular administration of gastrin-releasing peptide and its receptor antagonist RC-3095 on learned fear responses in the rat. Behav. Brain Res. 216, 519-524.

Minamino, N., Kangawa, K., and Matsuo, H. (1983). Neuromedin B: a novel bombesin-like peptide identified in porcine spinal cord. Biochem. Biophys. Res. Commun. 114, 541-548.

Minamino, N., Kangawa, K., and Matsuo, H. (1984). Neuromedin C: a bombesin-like peptide identified in porcine spinal cord. Biochem. Biophys. Res. Commun. 119, 14-20.

Moody, T. W., Getz, R., O’Donohue, T. L., and Rosenstein, J. M. (1988). Localization of receptors for bombesin-like peptides in the rat brain. Ann. N. Y. Acad. Sci. 547, 114-130.

Moody, T. W., and Merali, Z. (2004). Bombesin-like peptides and associated receptors within the brain: distribution and behavioral implications. Peptides 25, 511-520.

Moody, T. W., Mahmoud, S., Staley, J., Naldini, L., Cirillo, D., South, V. etal. (1989). Human glioblastoma cell lines have neuropeptide receptors for bombesin/gastrin-releasing peptide. J. Mol. Neurosci. 1, 235-242.

Moody, T. W., O'Donohue, T. L., and Jacobowitz, D. M. (1981). Biochemical localization and characterization of bombesin-like peptides in discrete regions of rat brain. Peptides 2, 75-79.

Moody, T. W., and Pert, C. B. (1979). Bombesin-like peptides in rat brain: quantitation and biochemical characterization. Biochem. Biophys. Res. Commun. 90, 7-14.

Moody, T. W., Pert, C. B., Rivier, J., and Brown, M. R. (1978). Bombesin: specific binding to rat brain membranes. Proc. Natl. Acad. Sci. U.S.A. 75, 5372-5376.

Moody, T. W., Staley, J., Zia, F., Coy, D. H., and Jensen, R. T. (1992). Neuromedin $\mathrm{B}$ binds with high affinity, elevates cytosolic calcium and stimulates the growth of small cell lung cancer cell lines. J. Pharmacol. Exp. Ther. 263, 311-317.

Mountney, C., Anisman, H., and Merali, Z. (2008). Effects of gastrinreleasing peptide agonist and antagonist administered to the basolateral nucleus of the amygdala on conditioned fear in the rat. Psychopharmacology (Berl.) 200, 51-58.

Mountney, C., Anisman, H., and Merali, Z. (2011). In vivo levels of corticotropin-releasing hormone and gastrin-releasing peptide at the basolateral amygdala and medial prefrontal cortex in response to conditioned fear in the rat. $\mathrm{Neu}$ ropharmacology 60, 410-417.

Mountney, C., Sillberg, V., Kent, P., Anisman, H., and Merali, Z. (2006). The role of gastrin-releasing peptide on conditioned fear: differential cortical and amygdaloid responses in the rat. Psychopharmacology (Berl.) 189, 287-296.

Niebergall-Roth, E., and Singer, M. V. (2001). Central and peripheral neural control of pancreatic exocrine secretion. J. Physiol. Pharmacol. 52, 523-538.

Oh, D. Y., Kim, K., Kwon, H. B., and Seong, J. Y. (2006). Cellular and molecular biology of orphan $\mathrm{G}$ protein-coupled receptors. Int. Rev. Cytol. 252, 163-218.

Ohki-Hamazaki, H., Iwabuchi, M., and Maekawa, F. (2005). Development and function of bombesin-like peptides and their receptors. Int. J. Dev. Biol. 49, 293-300.

Olincy, A., Leonard, S., Young, D. A., Sullivan, B., and Freedman, R. (1999). Decreased bombesin peptide response to cigarette smoking in schizophrenia. Neuropsychopharmacology 20, 52-59.

Petronilho, F., Vuolo, F., Galant, L. S., Constantino, L., Tomasi, C. D., Giombelli, V. R., et al. (2012). Gastrin-releasing peptide receptor antagonism induces protection from lethal sepsis: involvement of toll-like receptor 4 signaling. $\mathrm{Mol}$. $\mathrm{Med}$. doi: 10.2119/molmed.2012.00083. [Epub ahead of print].

Pinski, J., Schally, A. V., Halmos, G., Szepeshazi, K., and Groot, K. (1994). Somatostatin analogues and bombesin/gastrin-releasing peptide antagonist RC-3095 inhibit the growth of human glioblastomas in vitro and in vivo. Cancer Res. 54, 5895-5901.

Preissler, T., Luft, T., Kapczinski, F., Quevedo, J., Schwartsmann, G., and Roesler, R. (2007). Basic fibroblast growth factor prevents 
the memory impairment induced by gastrin-releasing peptide receptor antagonism in area CA1 of the rat hippocampus. Neurochem. Res. 32, 1381-1386.

Presti-Torres, J., de Lima, M. N., Scalco, F. S., Caldana, F., Garcia, V. A., Guimarães, M. R., et al. (2007). Impairments of social behavior and memory after neonatal gastrin-releasing peptide receptor blockade in rats: implications for an animal model of neurodevelopmental disorders. Neuropharmacology 52, 724-732.

Presti-Torres, J., Garcia, V. A., Dornelles, A., Halmenschlager, L. H., Alcalde, L. A., Vedana, G., et al. (2012). Rescue of social behavior impairment by clozapine and alterations in the expression of neuronal receptors in a rat model of neurodevelopmental impairment induced by GRPR blockade. J. Neural Transm. 119, 319-327.

Qiao, J., Kang, J., Ishola, T. A., Rychahou, P. G., Evers, B. M., and Chung, D. H. (2008). Gastrin-releasing peptide receptor silencing suppresses the tumorigenesis and metastatic potential of neuroblastoma. Proc. Natl. Acad. Sci. U.S.A. 105, 1289112896.

Rashidy-Pour, A., and Razvani, M. E. (1998). Unilateral reversible inactivations of the nucleus tractus solitarius and amygdala attenuate the effects of bombesin on memory storage. Brain Res. 814, 127-132.

Roesler, R., Brunetto, A. T., Abujamra, A. L., de Farias, C. B., Brunetto, A. L., and Schwartsmann, G. (2010). Current and emerging molecular targets in glioma. Expert Rev. Anticancer Ther. 10, 1735-1751.

Roesler, R., Henriques, J. A., and Schwartsmann, G. (2004a). Neuropeptides and anxiety disorders: bombesin receptors as novel therapeutic targets. Trends Pharmacol. Sci. 25, 241-242.

Roesler, R., Kopschina, M. I., Rosa, R. M., Henriques, J. A., Souza, D. O., and Schwartsmann, G. (2004b). RC3095, a bombesin/gastrin-releasing peptide receptor antagonist, impairs aversive but not recognition memory in rats. Eur. J. Pharmacol. 486, 35-41.

Roesler, R., Lessa, D., Venturella, R., Vianna, M. R., Luft, T., Henriques, J. A., et al. (2004c). Bombesin/gastrinreleasing peptide receptors in the basolateral amygdala regulate memory consolidation. Eur. J. Neurosci. 19, 1041-1045.

Roesler, R., Henriques, J. A., and Schwartsmann, G. (2006a). Gastrinreleasing peptide receptor as a molecular target for psychiatric and neurological disorders. CNS Neurol. Disord. Drug Targets 5, 197-204.

Roesler, R., Luft, T., Oliveira, S. H. Farias, C. B., Almeida, V. R., Quevedo, J., et al. (2006b). Molecular mechanisms mediating gastrin-releasing peptide receptor modulation of memory consolidation in the hippocampus. Neuropharmacology 51, 350-357.

Roesler, R., Kent, P., Schröder, N., Schwartsmann, G., and Merali, Z (2012). Bombesin receptor regulation of emotional memory. Rev. Neurosci. 23, 571-586.

Roesler, R., Meller, C. A., Kopschina, M. I., Souza, D. O., Henriques, J. A., and Schwartsmann, G. (2003). Intrahippocampal infusion of the bombesin/gastrin-releasing peptide antagonist RC-3095 impairs inhibitory avoidance retention. Peptides 24, 1069-1074.

Roesler, R., Valvassori, S. S., Castro, A. A., Luft, T., Schwartsmann, G., and Quevedo, J. (2009). Phosphoinositide 3-kinase is required for bombesin-induced enhancement of fear memory consolidation in the hippocampus. Peptides 30, 1192 1196.

Ruff, M., Schiffmann, E., Terranova, V., and Pert, C. B. (1985). Neuropeptides are chemoattractants for human tumor cells and monocytes: a possible mechanism for metastasis. Clin. Immunol. Immunopathol. 37, 387-396.

Rushing, P. A., Gibbs, J., and Geary, N. (1996). Brief, meal-contingent infusions of gastrin-releasing peptide127 and neuromedin B-10 inhibit spontaneous feeding in rats. Physiol. Behav. 60, 1501-1504.

Rushing, P. A., and Houpt, T. A. (1999). Gastrin-releasing peptide suppresses independent but not intraoral intake. Peptides 20, 737-741.

Sakamoto, H. (2010). The neurobiology of psychogenic erectile dysfunction in the spinal cord. J. Androl. 31, 519-526.

Sakamoto, H. (2011). Gastrin-releasing peptide system in the spinal cord mediates masculine sexual function. Anat. Sci. Int. 86, 19-29.

Sakamoto, H., and Kawata, M. (2009) Gastrin-releasing peptide system in the spinal cord controls male sexual behaviour. J. Neuroendocrinol. 21, 432-435.

Sakamoto, H., Matsuda, K., Zuloaga, D. G., Hongu, H., Wada, E., Wada, K., etal. (2008). Sexually dimorphic gastrin releasing peptide system in the spinal cord controls male reproductive functions. Nat. Neu rosci. 11, 634-636.

Sakamoto, H., Matsuda, K., Zuloaga, D. G., Nishiura, N., Takanami, K. Jordan, C. L., et al. (2009a). Stress affects a gastrin-releasing peptide system in the spinal cord that mediates sexual function: implications for psychogenic erectile dysfunction. PLoS ONE 4:e4276. doi: 10.1371/journal.pone. 0004276

Sakamoto, H., Takanami, K., Zuloaga, D. G., Matsuda, K., Jordan, C. L., Breedlove, S. M., et al. (2009b). Androgen regulates the sexually dimorphic gastrin-releasing peptide system in the lumbar spinal cord that mediates male sexual function. Endocrinology 150, 3672-3679.

Salio, C., Lossi, L., Ferrini, F., and Merighi, A. (2006). Neuropeptides as synaptic transmitters. Cell Tissue Res. 326, 583-598.

Santo-Yamada, Y., Yamada, K., Wada, E., Goto, Y., and Wada, K. (2003). Blockade of bombesin-like peptide receptors impairs inhibitory avoidance learning in mice. Neurosci. Lett. 340, 65-68.

Schmidt, A. L., de Farias, C. B., Abujamra, A. L., Kapczinski, F., Schwartsmann, G., Brunetto, A. L., et al. (2009). BDNF and PDE4, but not the GRPR, regulate viability of human medulloblastoma cells. J. Mol. Neurosci. 40, 303-310.

Schubert, M. L., Hightower, J., Coy, D. H., and Makhlouf, G. M. (1991). Regulation of acid secretion by bombesin/GRP neurons of the gastric fundus. Am. J. Physiol. 260, G156-G160.

Schwartsmann, G., DiLeone, L. P., Horowitz, M., Schunemann, D. Cancella, A., Pereira, A. S., et al. (2006). A phase I trial of the bombesin/gastrin-releasing peptide (BN/GRP) antagonist RC3095 in patients with advanced solid malignancies. Invest. New Drugs 24, 403-412.

Seidita, G., Mirisola, M., D’Anna, R. P., Gallo, A., Jensen, R. T., Mantey, S. A., et al. (2008). Analysis of the gastrinreleasing peptide receptor gene in Italian patients with autism spectrum disorders. Am. J. Med. Genet. B Neuropsychiatr. Genet. 147B, 807-813.

Sharif, T. R., Luo, W., and Sharif, M. (1997). Functional expression of bombesin receptor in most adult and pediatric human glioblastoma cell lines; role in mitogenesis and in stimulating the mitogen-activated protein kinase pathway. Mol. Cell. Endocrinol. 130, 119-130.

Shumyatsky, G. P., Tsvetkov, E. Malleret, G., Vronskaya, S., Hatton,
M., Hampton, L., et al. (2002). Identification of a signaling network in lateral nucleus of amygdala important for inhibiting memory specifically related to learned fear. Cell 111, 905-918.

Spindel, E. R., Chin, W. W., Price, J., Rees, L. H., Besser, G. M., and Habener, J. F. (1984). Cloning and characterization of cDNAs encoding human gastrin-releasing peptide. Proc. Natl. Acad. Sci. U.S.A. 81, 5699-5703.

Spindel, E. R., Giladi, E., Brehm, P., Goodman, R. H., and Segerson, T. P. (1990). Cloning and functional characterization of a complementary DNA encoding the murine fibroblast bombesin/gastrin-releasing peptide receptor. Mol. Endocrinol. 4, 1956-1963.

Stangelberger, A., Schally, A. V., Varga, J. L., Zarandi, M., Cai, R. Z., Baker, B., et al. (2005). Inhibition of human androgen-independent PC3 and DU-145 prostate cancers by antagonists of bombesin and growth hormone releasing hormone is linked to PKC, MAPK and c-jun intracellular signalling. Eur. J. Cancer 41, 2735-2344.

Stoddard, S. L., Tyce, G. M., Ahlskog, J. E., Zinsmeister, A. R., Nelson, D. K., and Carmichael, S. W. (1991). Decreased levels of [Met] enkephalin, neuropeptide Y, substance $P$, and vasoactive intestinal peptide in parkinsonian adrenal medulla. Exp. Neurol. 114, 23-27.

Sun, Y. G., and Chen, Z. F. (2007). A gastrin-releasing peptide receptor mediates the itch sensation in the spinal cord. Nature 448, 700-703.

Sun, Y. G., Zhao, Z. Q., Meng, X. L., Yin, J., Liu, X. Y., and Chen, Z. F. (2009). Cellular basis of itch sensation. Science 325, 1531-1534.

Szepeshazi, K., Schally, A. V., Halmos, G., Lamharzi, N., Groot, K., and Horvath, J. E.(1997). A single in vivo administration of bombesin antagonist RC-3095 reduces the levels and mRNA expression of epidermal growth factor receptors in MXT mouse mammary cancers. Proc. Natl. Acad. Sci. U.S.A. 94, 10913-10918.

Thaw, A. K., Smith, J. C., and Gibbs, J. (1998). Mammalian bombesin-like peptides extend the intermeal interval in freely feeding rats. Physiol. Behav. 64, 425-428.

Thomas, S. M., Grandis, J. R., Wentzel, A. L., Gooding, W. E., Lui, V. W., and Siegfried, J. M. (2005). Gastrinreleasing peptide receptor mediates activation of the epidermal growth factor receptor in lung cancer cells. Neoplasia 7, 426-431. 
Venturella, R., Lessa, D., Luft, T., Roozendaal, B., Schwartsmann, G., and Roesler, R. (2005). Dexamethasone reverses the memory impairment induced by antagonism of hippocampal gastrin-releasing peptide receptors. Peptides 26, 821-825.

von Schrenck, T., Heinz-Erian, P., Moran, T., Mantey, S. A., Gardner, J. D., and Jensen, R. T. (1989). Neuromedin $\mathrm{B}$ receptor in esophagus: evidence for subtypes of bombesin receptors. Am. J. Physiol. 256, G747G758.

von Schrenck, T., Wang, L. H., Coy, D. H., Villanueva, M. L., Mantey, S., and Jensen, R. T. (1990). Potent bombesin receptor antagonists distinguish receptor subtypes. Am. J. Physiol. 259, G468-G473.

Wada, E., Way, J., Lebacq-Verheyden, A. M., and Battey, J. F. (1990). Neuromedin B and gastrin-releasing peptide mRNAs are differentially distributed in the rat nervous system. $J$. Neurosci. 10, 2917-2930.
Wada, E., Way, J., Shapira, H., Kusano, K., Lebacq-Verheyden, A. M., Coy, D. et al. (1991). cDNA cloning, characterization, and brain region-specific expression of a neuromedin Bpreferring bombesin receptor. $\mathrm{Neu}$ ron 6, 421-430.

Wada, E., Wray, S., Key, S., and Battey, J. (1992). Comparison of gene expression for two distinct bombesin receptor subtypes in postnatal rat central nervous system. Mol. Cell. Neurosci. 3, 446-460.

Wang, L. H., Battey, J. F., Wada, E., Lin, J. T., Mantey, S., Coy, D. H., et al. (1992). Activation of neuromedin Bpreferring bombesin receptors on rat glioblastoma c-6 cells increases cellular $\mathrm{Ca}^{2+}$ and phosphoinositides. Biochem. J. 286, 641-648.

Williams, C. L., and McGaugh, J. L. (1994). Enhancement of memory processing in an inhibitory avoidance and radial maze task by posttraining infusion of bombesin into the nucleus tractus solitarius. Brain Res. 654, 251-256.
Wolf, S. S., and Moody, T. W. (1985). Receptors for GRP/bombesin-like peptides in the rat forebrain. Peptides 6(Suppl. 1), 111-114.

Wolf, S. S., Moody, T. W., O’Donohue, T. L., Zarbin, M. A., and Kuhar, M. J. (1983). Autoradiographic visualization of rat brain binding sites for bombesin-like peptides. Eur. J. Pharmacol. 87, 163-164.

Wong, S. T., Athos, J., Figueroa, X. A., Pineda, V. V., Schaefer, M. L., Chavkin, C. C., et al. (1999). Calcium-stimulated adenylyl cyclase activity is critical for hippocampusdependent long-term memory and late phase LTP. Neuron 23, 787-798.

Zarbin, M. A., Kuhar, M. J., O’Donohue, T. L., Wolf, S. S., and Moody, T. W. (1985). Autoradiographic localization of (125ITyr4)bombesin-binding sites in rat brain. J. Neurosci. 5, 429-437.

Conflict of Interest Statement: The authors declare that the research was conducted in the absence of any commercial or financial relationships that could be construed as a potential conflict of interest.

Received: 17 October 2012; paperpending published: 04 November 2012; accepted: 23 November 2012; published online: 17 December 2012.

Citation: Roesler R and Schwartsmann $G$ (2012) Gastrin-releasing peptide receptors in the central nervous system: role in brain function and as a drug target. Front. Endocrin. 3:159. doi: 10.3389/ fendo.2012.00159

This article was submitted to Frontiers in Neuroendocrine Science, a specialty of Frontiers in Endocrinology.

Copyright (c) 2012 Roesler and Schwartsmann. This is an open-access article distributed under the terms of the Creative Commons Attribution License, which permits use, distribution and reproduction in other forums, provided the original authors and source are credited and subject to any copyright notices concerning any third-party graphics etc. 